\title{
Darnaus vystymosi tikslų iggvendinimo analizė Baltijos šalyse
}

\author{
Kantautė Augaitytė \\ Kaunas University of Technology \\ A. Mickevičiaus 37, LT-44244 Kaunas, Lithuania \\ cross $^{\text {ref }}$ http://dx.doi.org/10.5755/j01.ppaa.19.1.25848
}

\begin{abstract}
Anotacija. Šiame straipsnyje yra analizuojami Baltijos šaliu pasiekimai siekiant darnaus vystymosi tikslu igyvendinimo. Analizuojama moksline literatūra, apibūdinanti darnaus vystymosi squvoką. Pateikiamas holistinis požiūris ị darnaus vystymosi suvokima ir kompleksiškas požiūris $i$ darnaus vystymosi siekima. Straipsnyje naudojamasi $2015 \mathrm{~m}$. Jungtiniu tautu darnaus vystymosi darbotvarke ir jos iškeltais tikslais. Visi tikslai, remiantis Tarptautinio taikomosios sistemos analizès instituto (angl. International Institute of Applied Systems Analysis - IIASA) duomenimis, suskirstomi ¿ pagrindines šešias sritis: visuotinès vertybès, tausus išteklių naudojimas, aplinkos salygos, žmogaus poreikiu patenkinimas, socialinis ir ekonominis augimas, valdymas ir partnerystè. Pagal šias sritis straipsnyje analizuojami pagrindiniai Baltijos šaliu rodikliai (Gini koeficientas, iš atsinaujinančiu šaltiniu gaunamos energijos dalis, šiltnamio efekta sukeliančiu duju emisijos, skurdo rizikos lygis, nedarbo lygis, valdžios išlaidos sveikatos priežiūrai ir švietimui, procentai nuo BVP). Pagal išanalizuotus rodiklius išskiriamos silpniausios sritys Baltijos šalyse ir šiose šalyse pastebimos tendencijos.
\end{abstract}

Keywords: sustainable development, Baltic states.

Raktažodžiai: darnus vystymasis, Baltijos šalys.

Ivadas

Darnus vystymasis apima tolygų ir visapusišką valstybių ir piliečių vystymąsi ilguoju laikotarpiu. Valstybių vystymosi svarba negali būti apibūdinama vienu teiginiu dèl savo plačios reikšmès. Darnus vystymasis ilgą laiką buvo suvokiamas kaip atskirų sričių, t.y. ekonominès, socialinès ir aplinkos apsaugos, vystymasis. Bet dèl kompleksiškos reikšmès darnaus vystymosi sąvoka tampa vis platesnè, nes pradedama suvokti, kad ši sąvoka ir jos pritaikymo būtinybė yra neatsiejama nuo valstybès gerovès ar socialinès gerovès sąvokų. Klaidinga manyti, jog vystymasis yra svarbus tik neišsivysčiusioms valstybėms, nes šiandieniniame pasaulyje, valstybès pradeda susidurti su tokiomis problemomis, kurių nebuvo iki šiol, arba yra vis dar neišsprendusios senų problemų. Darnus vystymasis yra siekiamybè visoms pasaulio valstybėms, nes taip galima užtikrinti saugų gyvenimą piliečiams, tvarią gamybą, kuri yra draugiška gamtai ir užtikrinti gamtos išteklius ateities kartoms. Naujausia ir dabar galiojanti yra Jungtinių Tautų kartu su Europos Sajunga sukurta „Darnaus vystymosi darbotvarkè 2030“. ES daug prisidejjo prie darbotvarkès sukūrimo, atliko tyrimus ir pabrèžè didžiausias problemas, todèl visoms ES šalims šie tikslai tampa tik dar labiau siektini, pasitelkiant „Europa 2020“, „Europa 2030“ ir kitas strategijas. Baltijos šalys: Lietuva, Latvija ir Estija, Europos Sajungoje nėra labiausiai pažengęs regionas, nes nei viena Baltijos šalis pagal bendraji vidaus produktą vienam gyventojui, pagal perkamosios galios standartą nesiekia ES vidurkio (Eurostat, 2019). Straipsnis atliktas remiantis baigiamuoju magistro projektu, atliktu Kantautès Augaitytès (2020). Mokslinių darbų ar tyrimų, analizuojančių Baltijos šalių regiono vystymąsi, yra pasigendama, bet šios šalys turi panašią istorinę raidą ir geografinę vietą, todèl gali būti analizuojamos kaip atskiras regionas, palyginant jų pasiekimus po nepriklausomybių atkūrimo. Šiame 
darbe iškeliamas straipsnio tikslas: atlikti darnaus vystymosi tikslų igyvendinimo analizę Baltijos šalyse. Tikslui pasiekti iškelti uždaviniai: 1) ịvardyti darnaus vystymosi sampratą, 2) išanalizuoti darnaus vystymosi rodiklius 2010-2017 m. Baltijos šalyse (Gini koeficientas, iš atsinaujinančių šaltinių gaunamos energijos dalis, šiltnamio efektą sukeliančių dujų emisijos, skurdo rizikos lygis, nedarbo lygis, valdžios išlaidos sveikatos priežiūrai ir švietimui, procentai nuo BVP).

\section{Darnaus vystymosi samprata}

Ekonomistai ir teoretikai apibūdindavo kapitalo sampratą kaip ekonominị augimą, bet ir žmogiškaji kapitalą (išsilavinimą ir igūdžius), socialinį kapitalą (socialinius santykius ir tinklus) ir gamtos kapitalą (gamtos išteklius ir ekosistemas) (Blewitt, 2012). Vis dèlto buvo prieita prie modernesnio požiūrio ị darnų vystymąsi. $1987 \mathrm{~m}$. Bruntland ataskaitoje teigiama, jog būtina tenkinti savo dabartinius poreikius nekenkiant ateities kartų galimybėms tenkinti jų poreikius, taip pat buvo teigiama, jog siekiant darnaus vystymosi, augalų bei gyvūnų gyvenimo sąlygos ir ekonominis augimas yra svarbiausi susiję ir vienas kitą veikiantys veiksniai. Griggs ir kiti (2013) siūlo trijų ramsčių sistemą: ekologinę, ekonominę ir socialinę aplinkas vertinti ir tobulinti kompleksiškai, neskirstat pagal pagrindines socialinę, ekonominę bei ekologinę aplinkas. Panašaus pobūdžio darnaus vystymosi apibrèžimas minėtoje $1987 \mathrm{~m}$. Bruntland ataskaitoje turètu būti perfrazuojamas ir traktuojamas taip: vystymasis, kuris tenkina poreikius saugodamas žemès išteklius ir kuriuo grindžiama gerové, priklauso nuo dabarties ir ateities kartų. Autoriai daugiausiai mini aplinkosaugos tikslus, kurie koreliuoja su socialine aplinka siekiant užtikrinti visuomenės sveikatą, mažinti badą bei skurdą, tačiau pabrěžia ir tai, kad nei vienas iš šių tikslų yra nepasiekiamas be pakeitimų ekonominèje srityje.

Pasak Čiegio, Diliaus ir Mikalauskienès (2014), ekonomikos augimas daro poveikị socialinei sričiai, nes per didelis gamybos augimas sumažina nedarbo lygi, o ji patvirtina didèjantis infliacijos lygis. Augantis infliacijos lygis sumažina realų darbo užmokestį, t.y. realias pajamas, ir taip padidèja skurdo lygis. Taigi, esant sparčiam ekonomikos augimui, lygiagrečiai didejja vartojimas, dèl šito eikvojami gamtos ištekliai, o taršos lygis didejja. Fiskalinės politikos sprendimai ir rodiklių pokyčiai gali daryti ịtaką socialinei aplinkai. Autoriai taip pat mini, kad didinant gamybą tarša gali ir mažèti, tačiau tik iki tam tikro lygio, todèl inovacijos ir naujų technologijų diegimas yra būtinas. Kadangi ekonomika gebėtų kontroliuoti ir tobulinti gamybą, verslas turi rasti alternatyvą vykdyti gamybą ir naudoti žaliavas, kurios būtų palankios aplinkai; taip gali būti užtikrinama tvari gamyba, prie kurios prisiderins ir visuomenè.

Pasak Marten (2010), vienas iš tinkamų pavyzdžių - dreifuojančių tinklų istorija. Tinklai būdavo nutiesiami kelių kilometrų ilgio atstumu. Žvejams tai buvo pelninga priemone gaudyti žuvims, tačiau bėgant metams buvo nustatyta, kad ị tinklus įsipainioja ir žūsta labai daug delfinų, ruonių ir kitų didelių gyvūnų. Gyvūnų apsaugos organizacijos pradèjo šviesti visuomenę ir skatinti vyriausybes uždrausti šių tinklų naudojimą. Kai kurių tautų vyriausybės neatsakè, bet kai kurios šią problemą perdavė JT, kurios priėmė nutarimą, kad visos tautos turètų sustoti naudoti dreifuojančius tinklus. Iš pradžių daugelis žvejų nenorèjo nustoti naudoti dreifuojančių tinklų, tačiau šalių vyriausybių priimti teisiniai aktai priverte juos keistis ir nustatė draudimus. Per kitus kelerius metus Žvejai perejo nuo dreifuojančių tinklų prie linijų su kabliukais tiesimo ir kitų naujų žvejybos būdų (Marten, 2010). Tai yra vienas iš daugelio pavyzdžių, kaip organizacijų ar visuomenès grupių judejjimai gali atnešti didelius pokyčius, parodydami stiprią sąsają tarp ekonomikos, socialinès ir aplinkosaugos sistemų.

Šiuo atveju gali labai stipriai prisidèti ir socialinè politika ir per ją organizuojamas dialogas su visuomene. Socialinè politika gali veikti per institucijas, kurios turi įtraukti visuomenę ir nevyriausybines organizacijas, nes, pasak Smalskio ir Šilinkytès (2016), piliečiams ir bendruomenèms įsitraukiant ị valdymą, viešoji politika gali tapti labai atvira, skaidri ir ịtrauki, todèl visuomenès dalyvavimas gali inicijuoti, sustabdyti ar kontroliuoti valdžios vykdomas programas.

Čiegio ir kt. (2015) teigimu, darnumas kaip sąvoka apima keturias sąlygas: darnumas turi gerinti gyvenimo kokybę, gerovę; turi būti atsižvelgiama i dabartines ir ateities kartas; turi būti 
igyvendinama lygybė bei teisingumas ir turi būti gyvenama darant mažesnị poveikị ekosistemoms. Autoriai pažymi, kadAgyeman J. (trūksta metų??) teigia, kad šalyse, kuriose pajamų nelygybė yra mažesnè, mažesnis ir oro bei vandens užterštumas. Pabrèžiant ir ekologijos srities tobulinimą, išskiriama, kad yra reikalingi sprendimai, kurie būtų kruopščiai suderinti, nes valstybès, turinčios didelę pajamų nelygybę, sunkiai iggyvendina klimato kaitos stabdymo priemones (Morel, Palier, Palmer, 2012). Pasak Augaitytès (2020), Gini koeficientas, parodantis pajamų nelygybę, Baltijos šalyse viršija ES vidurkị nuo 2010 m. Naujausiais duomenimis, 2017 m. rodiklis Estijoje siekè 31,6 Latvijoje - 36,4 \%, o Lietuvoje net 37,6 \%, o ES vidurkis buvo 30,6 \% Lyginant su 2017 metais, 2018 m. oro taršos lygis Baltijos šalyse padidèjo. Estijoje šis rodiklis padidejjo iki 8,8 \%, Latvijoje jis siekè 19,1\%, o Lietuvoje - $17 \%$, o ES vidurkis yra 14,9 \% (Eurostat, 2020). Kompleksiškumo svarba siekiant darnaus vystymosi igyvendinimo yra akivaizdi: jei formuojant ir igyvendinant politiką, reguliuojančią ekonomiką ir socialines organizacijas ar veiklas, neatsižvelgiama į aplinkos veiksnius, taikyti darnaus vystymosi modeli yra neįmanoma; jis ilgainiui turi tapti ekologiškas ir socialiai bei ekonomiškai tvarus (Murphy, 2012).

Pastaruoju metu ị darnų vystymąsi jau yra žvelgiama holistiniu požiūriu; pripažistama, kad ekonominè, socialinė ir ekologinė aplinkos yra tarpusavyje susijusios. Kiekviena problema turi būti sprendžiama ne atskirai, bet turi būti tobulinama ir per kitas sritis. Tokị kompleksišką požiūrị Sachs (2015) siūlo suvokti kaip žmogaus organizmą, kurị sudaro organų sistemos, kurios susietos audiniais ir ląstelèmis. Žmogaus organizme yra maždaug 10 trilijonų ląstelių visos jos sąveikauja tarpusavyje įvairiose sistemose (kraujotakos, nervų, virškinimo ir pan.), todèl pati ląstelè yra sąveikaujančių ląstelių sistema. Tai atitinka šiandieninę ekonomiką ir joje esančius milijonus asmenų ir verslo subjektų, susietų įvairiose rinkose. Šios kompleksiškos sistemos yra sudètingos, nes reakcija ị ịvairius dirgiklius gali būti netiesinè ir net ir labai maži pokyčiai vienoje sistemos dalyje gali sukelti didelius ar net katastrofiškus pokyčius visoje sistemoje (Sachs, 2015). Pavyzdžiui, skurdas kaip veiksnys yra kompleksiškas ir turi labai daug skirtingu priežasčių, todèl gali būti sprendžiamas ịvairiai, per įvairias sritis, tačiau sprendimo būdai taip pat turètų būti kompleksiški, o tai reikalauja unikalių sprendimų. Remiantis Skučiene (2018), skurdas yra susijęs ir su socialine atskirtimi, kuri gali apibūdinti nedalyvavimą darbo rinkoje, socialinę izoliaciją, pajamų trūkumą, kuris apima sveikatos, ugdymo ir būsto paslaugų prieinamumo problemas.

Apibendrinant, norint tikslingai siekti darnaus vystymosi, reikalingi tikslūs moksliniai tyrimai, kurie nustatytu visas galimas sąsajas tarp problemų ir sprendimų. Taip pat galima daryti prielaidą, kad bet kokia problema, esanti tam tikrame organizmo lygmenyje (sistemoje, organe), sukelia padarinius kitame. Taip pat ir atvirkščiai: gydydami tam tikrą „,organą“, galime išgydyti ir kitus susijusius „susirgimus ir visus simptomus“. Todèl tam tikras pakeitimas vienoje srityje gali išspręsti problemas kitoje srityje; tai pagrindžia kompleksiško požiūrio ị darnų vystymąsi naudą ir būtinumą.

\section{Darnaus vystymosi tikslai}

Jungtinių Tautų (JT) darbotvarkèje 2030 nustatyti 17 darnaus vystymosi tikslų. Kiekvienas tikslas turi uždavinius, per kuriuos yra siekiama tikslo ịgyvendinimo. Dẻl plačios darnaus vystymosi sąvokos ir dèl didelio skaičiaus iškeltų uždavinių šiame darbe siekiama ịvertinti Baltijos šalių pasiekimus vertinant tikslų ịgyvendinimą kompleksiškai. Remiantis Tarptautinio taikomujjų sistemų analizès (angl. International Institute for Applied Systems Analysis) instituto schema (2017), siūloma darnų vystymąsi vertinti kompleksiškai suvokiant, kad darnaus vystymosi tikslai yra universalūs, holistiniai ir tarpusavyje priklausomi, todèl nedalomi. Čia siūlomo orientacinio grupavimo vienintelis tikslas yra pabréžti žmonių gerovès, pasaulio raidos ir žemės sistemos stabilumo tarpusavio priklausomybę (Nakicenovic, 2017). Autorius išskiria pagrindines šešias sritis: visuotinès vertybès, tausus išteklių naudojimas, aplinkos sąlygos, pagrindiniai žmonių poreikiai, socialinis ir ekonominis vystymasis bei valdymas ir partnerystè. Oficialūs tikslų pavadinimai lietuvių kalba ịvardijami Darnaus vystymosi darbotvarkès iki $2030 \mathrm{~m}$. igyvendinimo Lietuvoje ataskaitoje, 2018 ???. Žemiau esančioje lentelëje vaizduojamos sritys su joms priklausančias tikslais ir tyrime naudojamais 
statistiniais rodikliais. Kiekvienai sričiai priklauso 2 arba 3 tarpusavyje labai susiję tikslai. Straipsnyje taikomas tyrimo metodas: antrinė kiekybinių duomenų analizè, kuria atliekama Baltijos šalių darnaus vystymosi tikslų igyvendinimo palyginamoji analizè. Šiame darbe bus analizuojamas vienas rodiklis kiekvienai sričiai, dėl straipsnio apimties apribojimų. Rodikliai atrinkti remiantis Sachs, J., SchmidtTraub, G., Kroll, C., Lafortune, G., Fuller, G. „Darnaus vystymosi ataskaita 2019 “ (angl. Sustainable development report, 2019). Rodikliai atrinkti pagal aktualumą šalies vystymuisi, poveiki kitoms sritims ir naujumą bei prieinamumą.

Lentele 1. Darnaus vystymosi sritys ir joms priskirti tikslai

\begin{tabular}{|c|c|c|}
\hline Sritis & Tikslai & Rodiklis \\
\hline Visuotinès vertybès & $\begin{array}{l}\text { 4. Užtikrinti visaapimantị ir lygiavertị kokybišką } \\
\text { švietimą ir skatinti visą gyvenimą trunkantị mokymąsi. } \\
\text { 5. Pasiekti lyčių lygybę ir ịgalinti moteris ir mergaites. } \\
\text { 10. Sumažinti nelygybę valstybėse ir tarp valstybių. }\end{array}$ & $\begin{array}{l}\text { Gini koeficientas Baltijos } \\
\text { šalyse. Šaltinis: Eurostat, } 2019 \\
\text { (Augaitytė, 2020:55) }\end{array}$ \\
\hline $\begin{array}{l}\text { Tausus ištekliu } \\
\text { naudojimas }\end{array}$ & $\begin{array}{l}\text { 6. Užtikrinti visiems vandens prieinamumą, darnų } \\
\text { valdymą ir sanitariją, tikslą. } \\
\text { 7. Užtikrinti visiems prieigą prie prieinamos, patikimos, } \\
\text { darnios ir modernios energijos. } \\
\text { 12. Užtikrinti darnaus vartojimo ir gamybos modelius. }\end{array}$ & $\begin{array}{l}\text { Iš atsinaujinančių šaltinių } \\
\text { gaunamos energijos dalis } \\
\text { Baltijos šalyse. Šaltinis: } \\
\text { Eurostat, } 2019 \text { (Augaitytė, } \\
\text { 2020:55) }\end{array}$ \\
\hline Aplinkos sąlygos & $\begin{array}{l}\text { 13. Imtis skubių kovos su klimato kaita ir jos padariniais } \\
\text { veiksmų } \\
\text { 14. Išsaugoti ir darniam vystymui naudoti vandenynų ir } \\
\text { jūrų išteklius. } \\
\text { 15. Saugoti, atkurti, skatinti darnų žemės ekosistemų } \\
\text { naudojimą, darniai valdyti miškus, kovoti su } \\
\text { dykumèjimu, sustabdyti žemės degradaciją, sustabdyti } \\
\text { bioịvairovès praradimą. }\end{array}$ & $\begin{array}{l}\text { Šiltnamio dujų emisijos \% } \\
\text { Baltijos šalyse. Šaltinis: } \\
\text { Eurostat, } 2020 .\end{array}$ \\
\hline $\begin{array}{l}\text { Žmogaus poreikiu } \\
\text { patenkinimas }\end{array}$ & $\begin{array}{l}\text { 1. Panaikinti visų formų skurdą. } \\
\text { 2. Panaikinti badą, užtikrinti apsirūpinimą maistu ir } \\
\text { geresnę mitybą, skatinti darnų žemės ūkị. } \\
\text { 3. Užtikrinti sveiką gyvenimą ir skatinti visų amžiaus } \\
\text { grupių gerovę. }\end{array}$ & $\begin{array}{l}\text { Skurdo rizikos lygis Baltijos } \\
\text { šalyse. Šaltinis: Eurostat, } \\
\text { 2019. (Augaitytè, 2020:42) }\end{array}$ \\
\hline $\begin{array}{l}\text { Socialinis ir } \\
\text { ekonominis augimas }\end{array}$ & $\begin{array}{l}\text { 8. Skatinti tvarų, visaapimantị ir darnų ekonominị } \\
\text { augimą, produktyvų įdarbinimą ir tinkamą darbą. } \\
\text { 9. Plètoti atsparią infrastruktūrą, skatinti visa apimančią } \\
\text { ir darnią industrializaciją ir skatinti inovacijas. } \\
\text { 11. Padaryti miestus ir žmonių apgyventas vietoves } \\
\text { saugias, atsparias ir darnias. }\end{array}$ & $\begin{array}{l}\text { Nedarbo lygis Baltijos šalyse. } \\
\text { Šaltinis: Eurostat, } 2019 . \\
\text { (Augaitytė, 2020:47) }\end{array}$ \\
\hline $\begin{array}{l}\text { Valdymas ir } \\
\text { partneryste }\end{array}$ & $\begin{array}{l}\text { 16. Skatinti taikias visuomenes darniam vystymuisi, } \\
\text { užtikrinti prieigą prie teisingumo visiems ir sukurti } \\
\text { efektyvias, atskaitingas visų lygių institucijas ir tikslą. } \\
\text { 17.Stiprinti vystymosi darbotvarkès ịgyvendinimo } \\
\text { priemones ir pagyvinti globalią partnerystę darniam } \\
\text { vystymuisi. }\end{array}$ & $\begin{array}{l}\text { Darnaus vystymosi } \\
\text { igyvendinimo ataskaita } 2019 \\
\text { (angl. sustainable } \\
\text { development report, 2019) } \\
\text { Rodiklis: „valdžios išlaidos } \\
\text { Sveikatos priežiūrai ir } \\
\text { švietimui, procentai nuo BVP“‘ }\end{array}$ \\
\hline
\end{tabular}

Šaltinis: K. Augaitytè, 2020

Analizuojant visuotines vertybes naudojamas rodiklis „Gini koeficientas”, parodantis pajamu nelygybę. Ši nelygybè gali iš dalies atspindèti skurdo lygi šalyje, be kurio darnus vystymasis neigyvendinamas. Tausus ištekliu naudojimas analizuojamas per rodiklị „Iš atsinaujinančių šaltinių gaunamos energijos dalis“, nes pagal strategiją „Europa 2020“ yra siekiama atsinaujinančios 
energijos dali padidinti $20 \%$ Aplinkos sąlygoms analizuoti yra svarbiausias Europos Vadovų Tarybos nutarimas dèl dar dviejų pagrindinių $2030 \mathrm{~m}$. tikslų: bent $40 \%$ sumažinti šiltnamio efektą sukeliančių dujų išmetimą (palyginti su 1990 m.), ir mažiausiai $27 \%$ pagerinti energijos vartojimo efektyvumą (Europa 2020, 2020). Pagrindiniai žmogaus poreikiai analizuojami per skurdo rodikli, kadangi strategijoje yra siekiama sumažinti skurdo ar socialinès atskirties riziką 20-čiai milijonų žmonių. Socialinis ir ekonominis augimas analizuojamas pagal nedarbo lygi šalyje, kadangi tai gali atspindèti darbo vietų trūkumą šalyje, o dèl jo ekonominis augimas vyktų kur kas lèčiau. Valdymas ir partneryste analizuojama pagal valdžios išlaidas sveikatos priežiūrai ir švietimui procentais nuo BVP, kadangi tai užtikrintų skaidrią partnerystę. Antrinių duomenų analizė nėra veikiama išorinių faktorių, o jų kaita fiksuojama dažniausiai kas metus, todèl šis tyrimas yra tikslesnis negu kiekybinis. Šis tyrimas tinkamas analizuojant plačiają visuomenę, t.y. valstybès atveji (Kardelis, 2002).

\section{Baltijos šalių darnaus vystymosi rodiklių palyginamoji analizė}

Pabrěžiama, jog analizèje naudojami duomenys gali būti parenkami individualiai pagal analizuojamas sritis ir pagal orientacines sritis. Šiame straipsnyje siekiama atspindèti kompleksiško vertinimo tinkamumą vertinant darnų vystymąsi. Rodiklių naudingumas bei svarba gali būti vertinamas kitaip, priklausomai nuo tyrimo. Šiame straipsnyje naudojami rodikliai išsiskiria iš kitų rodikliu savo tendencijomis. Neteigtina, jog vienas srities rodiklis atspindi visos srities rezultatus šalyje, tačiau gali būti daromos prielaidos apie tam tikras tendencijas.

Pirma nagrinejama sritis yra visuotinès vertybès. Šiuo atveju didesnè svarba keliama pajamų nelygybei. Pasak Skučienès (2008), pajamų nelygybė yra svarbi, nes gali veikti neigiamų reiškinių augimą, o tai gali apimti nepakankamai geras būsto sąlygas, visuomenės grupés prastejjanti sveikata, kuri veikia mirtingumo rodiklius. Dalis visuomenès gali neturèti tinkamo prieinamumo prie kokybiško švietimo, tai gali sąlygoti mažesni politini aktyvumą; pajamų nelygybė gali sukelti finansines problemas šeimose, dèl jų gali būti pastebima didelè emigracija. Vertinant duomenis pagal 1 paveikslą, matoma, kad pajamų nelygybė didžiausia Lietuvoje ir jos rodiklis yra beveik toks pats kaip ir 2010 m. - 37; gal ir buvo pasiekta pažanga iki 2012 m., tačiau vèliau pastebimas skirtumo didejjimas. Latvijos Gini koeficientas 2017 m. siekè 34,5, o Estijos 31,6, o ES vidurkis yra 30,6. Visos Baltijos šalys viršija šio rodiklio ES vidurkį.

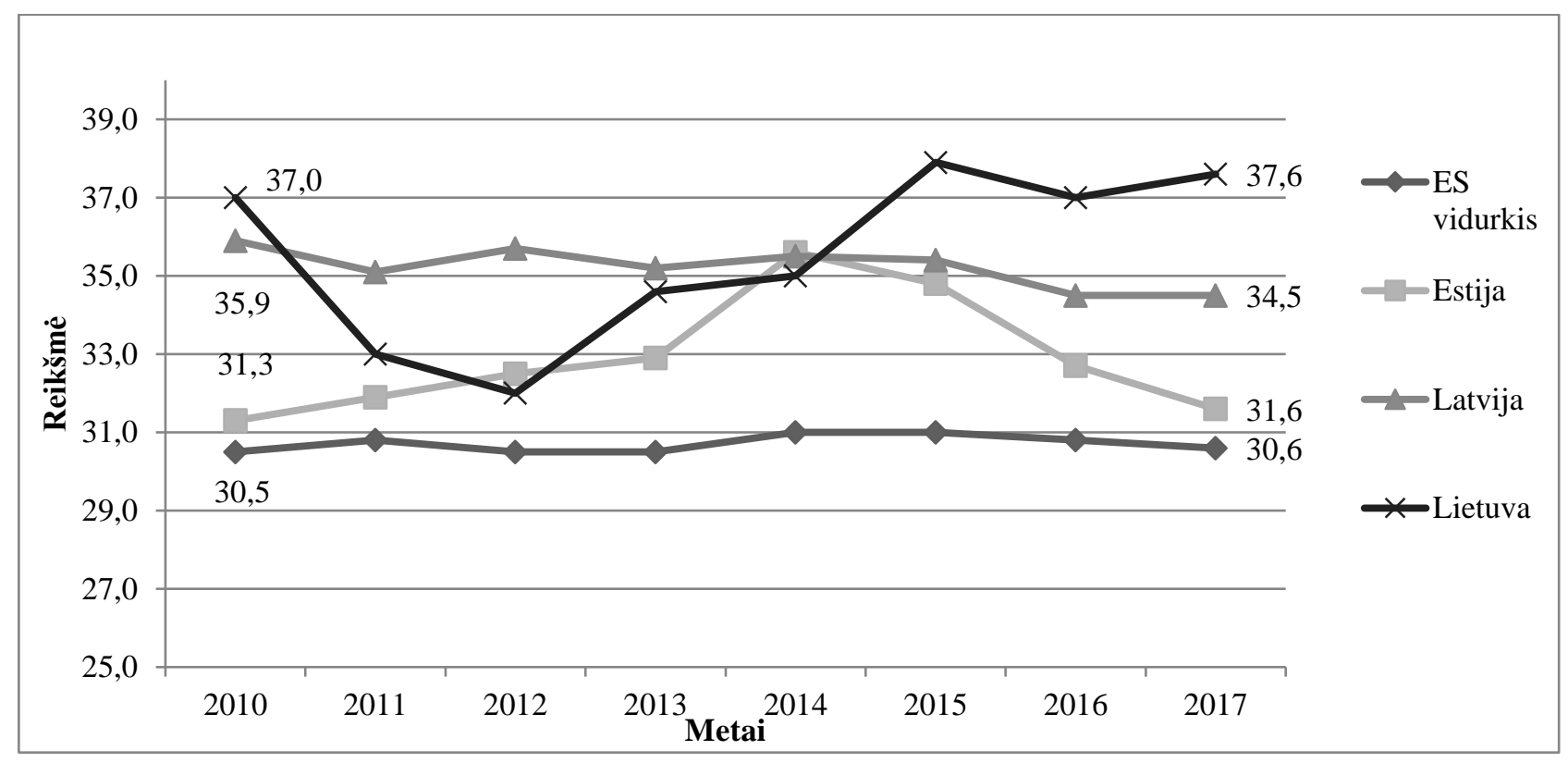

Pav. 1. Gini koeficientas Baltijos šalyse

Šaltinis: Eurostat, 2019 (Augaitytè, 2020:55) 
Analizuojant tausu ištekliu naudojima, vienas svarbiausių aspektų yra atsinaujinančių išteklių naudojimas. Atsinaujinančių išteklių naudojimas daugeliu atveju vykdomas tam tikrame vietiniame lygmenyje ir nereikalauja centralizuotos techninès struktūros. Autonominès technologijos gerai integruojasi ị regioninès ir vietinès plètros politiką, strategiją ir planus. Itvertinant autonomini atsinaujinančių energijos išteklių prieinamumą, atsinaujinanti energija gali tapti veiksniu, skatinančiu ekonominę plètrą visame regioniniame lygyje. Atsinaujinančių energijos išteklių atnešama nauda gali būti tiek ekonominè, tiek socialinè. Didžiausias efektyvumas kol kas yra vėjo energijos, o mažiausias - saulès energijos. Hidroenergija yra pigiausia, o efektyvumas gali siekti net $90 \%$ (Kveselis, Dzenajavičienė, Lisauskas, 2013). Pabrezžiama, jog visos Baltijos šalys viršija ES vidurkị, didžiausia energijos dalis iš atsinaujinančių šaltinių pagaminama Latvijoje net $39,01 \%$, beveik $10 \%$ mažiau Estijoje ir mažiausiai Lietuvoje, kadangi didžiają dalị energijos Lietuva perka iš užsienio valstybių.

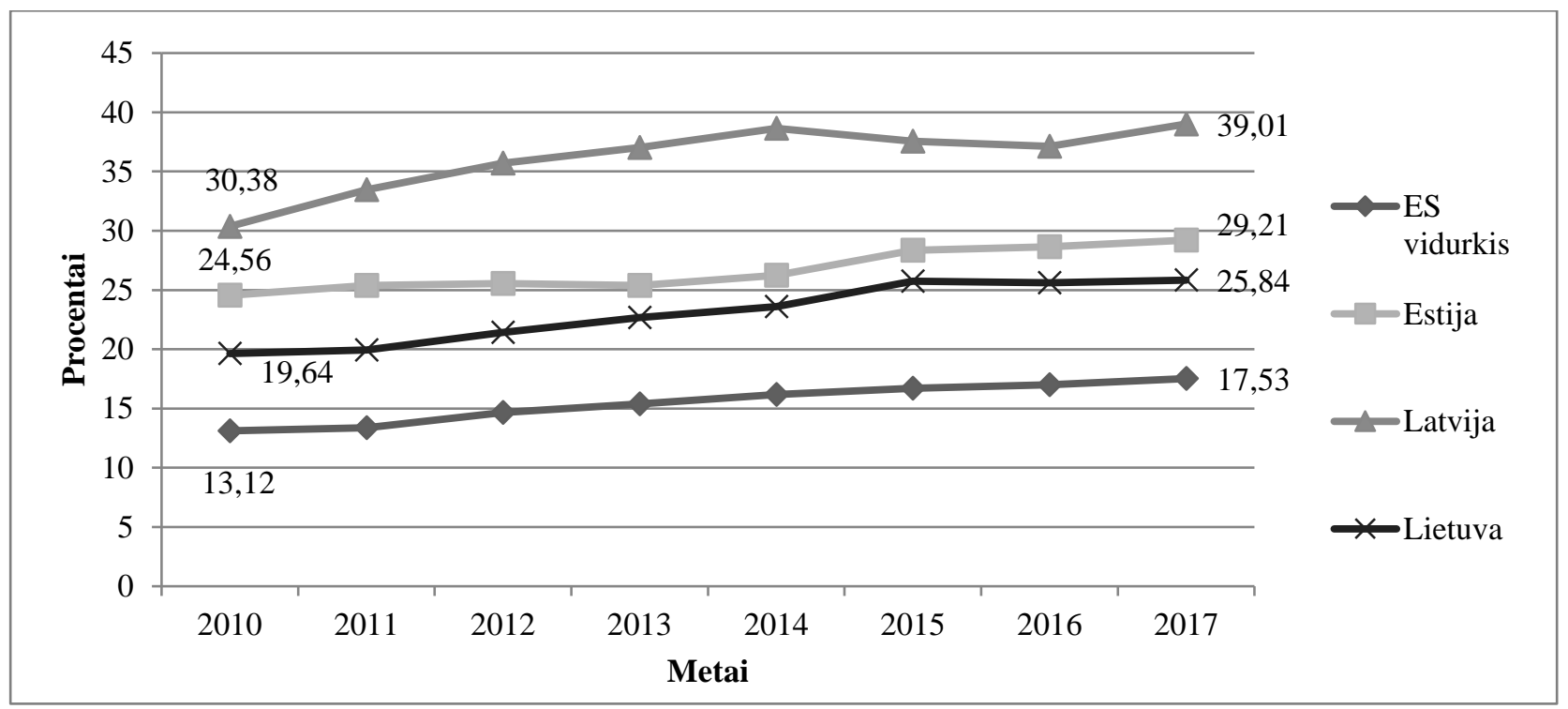

Pav. 2. Iš atsinaujinančių šaltinių gaunamos energijos dalis Baltijos šalyse

Šaltinis: Eurostat, 2019 (Augaitytè, 2020:55)

Analizuojant aplinkos sąlygas būtina analizuoti ne tik šiltnamio dujų emisijas, bet atskirai ir anglies dioksido emisijas, kadangi jos sudaro didžiausią dalị šiltnamio dujų efekto. Pasak Urbanavičiūtès ir Ruzevičiaus (2016), CO2 aplinkoje gali išlikti 50-200 metų, o šiuo metu emisijos yra didžiausias per pastaruosius 650000 metų. Lietuvoje $2010 \mathrm{~m}$. CO2 buvo išskiriamos iš keturių sektorių: energetikos (26\%), pramonès (24\%), transporto (22\%) bei žemės ūkio $(21 \%)$. Pramonè ir atliekos kartu susumavus sudaro beveik trečdalį visų pagrindinių šiltnamio efektą sukuriančių dujų. Taigi vartojimas gali būti vienas iš svarbiausių klimato kaitos veiksnių (Urbanavičiūtė, Ruzevičius, 2016). Analizuojant Baltijos šalių CO2 emisijas didžiausios emisijos yra Estijoje (18.186.109 tonų) ir Lietuvoje (17.325.736 tonų), o mažiausios - Latvijoje (6.908.160) (Augaitytė, 2020). Šiltnamio dujų emisijos, kurios apima anglies dioksidą (CO2), metaną $(\mathrm{CH} 4)$, azoto oksidą $(\mathrm{N} 2 \mathrm{O})$ ir kt. turi tendenciją mažèti nuo $2010 \mathrm{~m}$. iki $2017 \mathrm{~m}$. ES vidurkis sumažèjo 1 tona vienam gyventojui per metus, didžiausia šiltnamio dujų kaita pastebima Lietuvoje, kuri nuo $2010 \mathrm{~m}$. iki $2017 \mathrm{~m}$. padidejjo 0,6 tonomis, Latvijoje padidejo 0,1 tona, o Estijoje emisija nežymiai kito, tačiau $2010 \mathrm{~m}$. buvo tokia pati kaip 2017 m. Lyginant su „Europa 2020“ tikslu šiltnamio dujų emisijas sumažinti bent 20 \% pažanga beveik nepastebima. 
Lentelè 2. Šiltnamio dujų emisijos tonos vienam gyventojui Baltijos šalyse

\begin{tabular}{|c|c|c|c|c|c|c|c|c|}
\hline Valstybé/metai & 2010 & 2011 & 2012 & 2013 & 2014 & 2015 & 2016 & 2017 \\
\hline ES vidurkis & 9,8 & 9,5 & 9,3 & 9,1 & 8,7 & 8,8 & 8,7 & 8,8 \\
\hline Estija & 16 & 16,1 & 15,4 & 16,8 & 16,2 & 13,9 & 15,1 & 16 \\
\hline Latvija & 6 & 5,8 & 5,8 & 5,8 & 5,8 & 5,9 & 6 & 6,1 \\
\hline Lietuva & 6,7 & 7,1 & 7,2 & 6,8 & 6,9 & 7 & 7,1 & 7,3 \\
\hline
\end{tabular}

Šaltinis: Eurostat, 2020

Pagrindiniai žmogaus poreikiai - fiziologiniai poreikiai, kurių patenkinimas yra svarbiausias. Galima daryti ịvairių prielaidų, tačiau klasikine Maslow'o poreikių piramide šiuo atveju labai tinkama (McLeod S, 2018). Piramidès pirmoje dalyje ịvardijami svarbiausi poreikiai, pvz., maistas, vanduo, šiluma ir poilsis. Kad ir kokios kritikos šis požiūris gali sulaukti, akivaizdu, kad asmuo, kuris badauja, negali pailsèti ar turi rimtų sveikatos sutrikimų, negali pilnai ir efektyviai dalyvauti darbo rinkoje. Su minètomis problemomis ne retai susiduria asmenys, kurie kenčia finansinį nepriteklių arba skurdą. Pastaraisiais metais yra fiksuojamas skurdo fenomenas, kuris atspindi dirbančiųju skurdo lygio augimą. Lietuvos dirbančiųjų skurdas gali būti sukuriamas dèl per mažų atlyginimų, sukuriamų darbo rinkos, tačiau gali būti ir kitų priežasčių (Gruževskis, Brazienè, Krutulienė, 2017). Dirbančiujų skurdo problema ypač aktuali Estijoje, kadangi joje 2018 metais skurdo lygis siekè 9,5 \% ir viršijo ES vidurkį, o Lietuvoje ir Latvijoje siekè 8,3 \% Pagrindinè dirbančiųjų skurdo priežastis gali būti aukštojo išsilavinimo stoka Estijoje. Lietuvoje $55 \%$ žmonių turi aukštuosius išsilavinimus, tad dirbančiujų skurdo priežastys gali būti visai kitos nei Estijoje (Augaitytė, 2020). Analizuojant skurdo lygi, didžiausias skurdo lygis fiksuojamas Latvijoje ir Lietuvoje - 28,3 \% Mažiausias yra Estijoje, tačiau visos Baltijos šalys viršija ES vidurkị.

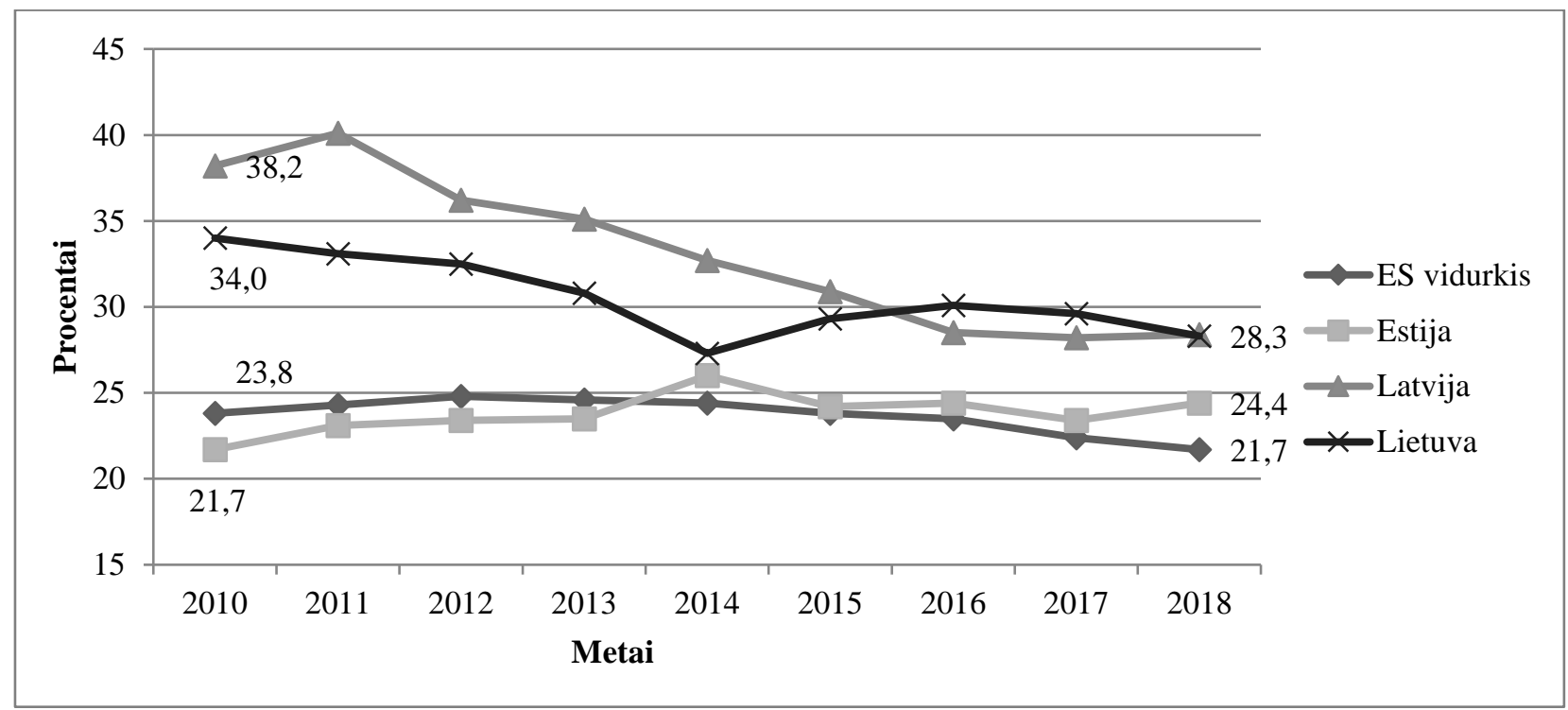

Pav. 3. Skurdo rizikos lygis Baltijos šalyse

Šaltinis: Eurostat, 2019 (Augaitytè, 2020:42)

Socialinis ir ekonominis augimas gali būti analizuojamas pagal nedarbo lygị šalyje. Nedarbo lygis ne tik atspindi ekonominị vystymąsi, bet ir gali parodyti tam tikras socialines problemas šalyje. Pagal Jurgos Bučaitės-Vilkès (2014), atliktą tyrimą nustatyta, kad jauni ir nedirbantys vyrai parodo politinių galių praradimo aspektus bei matoma socialinė marginalizacija, jų turimi socialiniai tinklai fragmentiški, o vyrai, turintys aukštesnị išsilavinimą, labiau naudojasi sukauptu socialiniu kapitalu ir siekia sumažinti nedarbo situacijos sąlygotas ịvairias rizikas. Iš esmès kiekvienas individas prisideda prie bendruomenès charakteristikos. Nedirbantys asmenys dèl savo pažeidžiamumo gali nesugebėti 
pakeisti savo statuso, nustoti domètis aktualijomis, naujovèmis, parasti motyvaciją dèl finansinio nepritekliaus ar išsilavinimo stokos. Remiantis Baltijos šalių duomenimis, fiksuojamas nedarbo lygio mažejjimas visose šalyse 2009-2018 metų laikotarpiu. 2018 m. Latvija viršija ES vidurkị ir susiduria su nedarbo lygiu, siekiančiu 5,2 \% Estijoje nedarbo lygis mažiausias ir nesiekia ES vidurkio.

Lentele 3. Nedarbo lygis Baltijos šalyse

\begin{tabular}{|c|c|c|c|c|c|c|c|c|c|}
\hline Šalis/Metai & 2010 & 2011 & 2012 & 2013 & 2014 & 2015 & 2016 & 2017 & 2018 \\
\hline ES vidurkis (\%) & 6,1 & 6,1 & 6,7 & 6,9 & 6,5 & 6,0 & 5,5 & 4,9 & 4,4 \\
\hline Estija (\%) & 11,1 & 8,3 & 6,8 & 5,9 & 5,0 & 4,3 & 4,8 & 4,1 & 3,9 \\
\hline Latvija (\%) & 12,6 & 10,4 & 9,9 & 7,8 & 7,2 & 6,7 & 6,6 & 6,0 & 5,2 \\
\hline Lietuva (\%) & 11,1 & 9,8 & 8,6 & 7,6 & 7,1 & 6,1 & 5,3 & 4,8 & 4,3 \\
\hline
\end{tabular}

Šaltinis: Eurostat, 2019 (Augaitytè, 2020:47)

Valdymas ir partnerystė gali būti analizuojama pagal korupcijos balą. Teigtina, kad didelè korupcija valstybèje gali turèti ịtakos šalies skurdo lygiui ir atsilikimui (Palidauskaité, 2005). Korupcijos balas yra didžiausias Latvijoje - 41, šiek tiek mažesnis Lietuvoje - 38 ir mažiausias Estijoje - 18 (Trading economics, 2019). Remiantis Darnaus vystymosi igyvendinimo ataskaita 2019, (angl. Sustainable Development Report, 2019) analizuojamas rodiklis ir šiame straipsnyje yra „valdžios išlaidos sveikatos priežiūrai ir švietimo procentai nuo BVP“. Visų šalių rodikliai turèjo tendenciją mažèti, todèl ši sritis tarp Baltijos šalių yra vertinama nepakankamai gerai.

Išanalizavus visas sritis matoma, jog Lietuvos prasčiausi rodikliai yra „,skurdo lygis“ ir ,,iš atsinaujinančių šaltinių gaunamos energijos dalis“ ir „Gini koeficientas“. Estijos prasčiausias rodiklis - „šiltnamio dujų emisijos“ ir fiksuojamas Gini koeficiento padidejimas. Latvijos prasčiausi duomenys yra „,nedarbo lygis“, „skurdo lygis“. Kiekvieno iš šių darnaus vystymosi igyvendinimas yra labai svarbus siekiant darnaus vystymosi tikslų, kadangi liko dešimt metų iki Jungtinių Tautų darbotvarkès tikslų igyvendinimo, o dabar, 2019 metais, t.y. po 5-erių metų nuo darbotvarkès sukūrimo, yra tikslinga vertinti pokyčius šalyse. Lyginant su ES vidurkiu Baltijos šalys viršija ES vidurkị su iš atsinaujinančių šaltinių energijos dalimi; visos šalys viršija ES vidurkị skurdo lygyje, o tai neigiamai veikia šalių vystymąsi. Pagal rezultatus galima matyti silpnąsias sritis šalyse. Lietuva silpnesnè sprendžiant pragyvenimo galimybių klausimus, taip pat energijos gamybos srityje, nes didelę dali jos perka iš užsienio šalių; taip pat yra fiksuojamas atlyginimo tarp lyčių skirtumo didejimas. Latvija pasižymi socialinèmis ir darbo rinkos problemomis. Estijoje fiksuojamas didelès šiltnamio dujų emisijos, kurios parodo naujų technologijų ir mažinimo priemonių būtinumą. Taip pagrindžiama stipri darnaus vystymosi tikslų igyvendinimo sąsaja su socialine politika. Per šios politikos sudedamąsias dalis: edukacinę (švietimo) politiką, šeimos politiką, sveikatos politiką, būsto politiką, migracinę politiką, užimtumo politiką bei socialinę pagalbą galima pasiekti teigiamų darnaus vystymosi rezultatų būtent dèl plataus politikos pritaikymo. Veikdama per užimtumo bei socialinès pagalbos politikas, socialinè politika gali prisidèti prie skurdo mažinimo, nedarbo lygio mažinimo. Socialinè politika taip pat gali prisidèti prie vartojimo mažinimo, prie gyventojų ekologiškos elgsenos, kai institucijos kuria dialogą su visuomene. Latvija pirmauja iš atsinaujinančių išteklių gamybos kiekiu bei mažiausiu išmetamų šiltnamio dujų kiekio rodikliu. Estijoje mažiausias skurdo lygis iš visų Baltijos šalių, taip pat mažiausias nedarbas ir mažiausias korupcijos balas.

\section{Tyrimo rodiklių palyginimas su Darnaus vystymosi ataskaitos 2019 m. rezultatais}

Remiantis Darnaus vystymosi igyvendinimo ataskaita 2019 (angl. sustainable development report, 2019), galima teigti, kad Estija užima 10 vietą iš 162 valstybių globaliu mastu. Tačiau fiksuojama stagnacija 10 tiksle (nelygybès mažinimas), 13 tiksle (aplinkosaugos priemonès), bei 17 tiksle (partnerystè). Latvija užima 24 vietą iš 32 ir stagnacija fiksuojama ties tais pačiais tikslais kaip ir Estijoje. Lietuva užima 32 vietą iš 162 ir nors nesusiduria su stagnacija, tačiau keliuose tiksluose 
yra fiksuojamas rodiklių blogėjimas: 10 tikslas (nelygybės mažinimas), 13 tikslas (aplinkos apsauga), 17 tikslas (partnerystè); dèl šių rodiklių blogèjimo globalus DV reitingas Lietuvoje tampa mažiausias iš visų Baltijos šalių. Pagrindžiant tyrimo naudingumą, pagal atliktą tyrimą ir Darnaus vystymosi igyvendinimo ataskaitos 2019 tikslus, ties kuriais yra fiksuojama stagnacija arba blogejimas, rezultatai sutampa. 10 tikslas (nelygybès mažinimas) atspindi straipsnyje minètą „Gini koeficientą“, kur blogiausia situacija Lietuvoje, kiek geresnè Latvijoje ir geriausia Estijoje (visų šalių rodiklis mažesnis nei ES vidurkis), 13 tikslas (aplinkos apsauga) atitinka straipsnyje analizuotą rodikli „šiltnamio dujų emisijos“, kurios Estijoje išliko vienodos, Latvijoje padidèjo nežymiai, o Lietuvoje padidejjo 0,6 \% 17 tikslas (partnerystė), atitinka minètą rodiklị ,,valdžios išlaidos sveikatos priežiūrai ir švietimui, procentai nuo BVP“, kuris visose šalyse mažejo, dėl ko tikslas laikomas neigyvendintu. Baltijos šalys bendrai yra silpniausios nelygybès mažinime, aplinkosaugos bei partnerystės srityje.

Siekiant darnaus vystymosi tikslų autore siūlo imtis pajamų nelygybės mažinimo priemonių, išskiriant silpniausias grupes, pvz., pensininkai, studentai, jaunos šeimos, neiggalieji. Išmokų padidinimas labiausiai pažeidžiamoms grupėms galètų suvienodinti gaunamas pajamas. Aplinkos apsaugos srityje pagrindinè ir svarbiausia užduotis sumažinti šiltnamio dujų, tarp jų ir CO2, emisijas. Vienas iš būdų yra riboti miškų kirtimą, labiau kontroliuoti CO2 leidimus gamybos vienetams, ypač nemokamai išdalinamus, uždrausti eksploatuoti senus ir taršius sunkvežimius, suteikti galimybes gyventojams įsigyti mažiau taršius automobilius reguliuojant jų kainas. Partnerystės srityje svarbu ne tik išlaidos švietimui bei sveikatos priežiūrai, bet ir gyventojų, NVO ịtraukimas ị valstybės valdymą. Sprendžiant aktualiausias problemas nevertètų pamiršti skurdo mažinimo priemonių.

\section{Išvados}

1. Darnus vystymasis gali būti laikomas sėkmingu, kai valstybė yra socialiai, ekonomiškai ir ekologiškai tvari. Suvokiant darnų vystymąsi kaip kompleksiškų sprendimų prièmimą, jo igyvendinimas būtų kur kas sèkmingesnis. Darnų vystymąsi siūloma analizuoti kompleksiškai, nes tam tikros tendencijos valstybėse atsispindi ir analizuojant pagrindinius šalių rodiklius.

2. Nagrinėjant visuotines vertybes kaip sriti pagal Gini koeficientą, didžiausias skirtumas matomas Lietuvoje, kurios reikšmė yra 37,6, o ES vidurkis - 30,6. Tausaus išteklių naudojimo srityje pagal rodikli , ,iš atsinaujinančių šaltinių gaunamos energijos dalis“ didžiausią energijos dali gauna Latvija, o mažiausią Lietuva, kuri didžiają dalį energijos perka iš užsienio šalių. Nors visos valstybès viršija ES vidurkị, Lietuvai ir Estijai vertètų pasiekti Latvijos energijos dalies procentą. Aplinkos sąlygų srityje analizuojant šiltnamio dujų emisijas nustatyta, kad didžiausios emisijos fiksuojamos Estijoje, o mažiausios Latvijoje. Šioje srityje yra būtinos emisijų mažinimo priemonès, nes Estijoje kiekis viršijamas beveik dvigubai nei ES vidurkis.

3. Pagrindiniai žmogaus poreikiai analizuojami pagal skurdo lygį; pagal rezultatus mažiausias skurdo lygis fiksuojamas Estijoje, o Latvijoje ir Lietuvoje skurdo lygis siekia beveik $30 \%$, tai rodo kad skurdo mažinimo priemonès yra būtinos ir turi būti sprendžiamos nuosekliai. Socialinis ir ekonominis augimas gali būti analizuojamas per nedarbo lygị, kuris Latvijoje visą analizuojamą laikotarpi išsilaiko didžiausias, todèl šioje srityje yra reikalingi sprendimai išaiškinant nedarbo lygio priežastis ir jas mažinant. Valdymo ir partnerystès srityje vienas svarbiausių aspektų valdžios išlaidų sveikatos priežiūrai ir švietimui mažejjimas, kuris atspindi 17 tikslo neigyvendinimą.

4. Atlikus tyrimą buvo nustatyta, jog Baltijos šalių rodiklių rezultatai sutapo su JT „Darnaus vystymosi igyvendinimo ataskaita 2019“ Baltijos šalių ataskaitomis. Analizuojant darnaus vystymosi igyvendinimą kompleksiškai, pagal pateiktas šešias sritis, įmanoma nustatyti orientacinę srities situaciją šalyje. Analizuojant po vieną svarbiausią rodiklị kiekvienai sričiai (visuotinès vertybès, tausus išteklių naudojimas, aplinkos sąlygos, žmogaus poreikių patenkinimas, socialinis ir ekonominis augimas, valdymas ir partnerystè) galima pastebèti pagrindines tendencijas šalyje, nes kiekvienas rodiklis gali turèti priklausomą kintamajj rodiklį ir tam tikros tendencijos neretai atsispindi keliuose rodikliuose. Šis tyrimo metodas gali būti tinkamas siekiant greitai nustatyti bendrą situaciją šalyje, atrankos būdų išskiriant tyrimui aktualius rodiklius, galima pastebèti teigiamus bei neigiamus aspektus valstybejje. 


\section{Literatūra}

1. Augaitytė K. Baltijos šalių darnaus vystymosi tikslų igyvendinimo analizè. Baigiamasis magistro studijų projektas. Kauno technologijos universitetas. Socialinių, humanitarinių mokslų ir menų fakultetas, Kaunas, 2020.

2. Blewitt J. Understanding Sustainable Development. London, Sterling VA, 2012. [žiūrèta 2020-02-25]. Internetine prieiga: https://www.academia.edu/23743702/Understanding_Sustainable_Development

3. Bučaitè-Vilkè J. 2014. Ar nedarbas riboja? Bendruomeniškumas, socialiniai paramos tinklai ir dalyvavimas viešajame gyvenime. Kultūra ir visuomenè. Vytauto Didžiojo Universitetas, 2014. http://dx.doi.org/10.7220/2335-8777.5.2.2

4. Čiegis ir kiti. (2015). Darnaus vystymosi problemos ir jų sprendimai Lietuvoje. Kolektyvinè monografija. Vilniaus universitetas, Aleksandro Stulginskio universitetas. [žiūrèta 2020-0225]. Internetinè prieiga: https://www.researchgate.net/profile/Indre_Siksnelyte/publication /321917951_Sustainability_assessment_of_electricity_market_in_Lithuania/links/5a397e2a a6fdcc34776a2b18/Sustainability-assessment-of-electricity-market-inLithuania.pdf\#page $=10$.

5. Čiegis R., Dilius A., Mikalauskienė A., 2014. Darnaus vystymosi sričių dinamikos vertinimas Lietuvoje. Vytauto Didžiojo universitetas, Vilniaus universitetas, Šiaulių universitetas, Lietuvos energetikos institutas (Lietuva). Regional Formation and Development Studies, No. 1 (11): 45-59. [žiūrèta 2020-02-25]. Internetinè prieiga: http://193.219.76.12/index.php/RFDS/article/view/685/pdf.

6. Eurostat, 2020. Bendrasis vidaus produktas vienam gyventojui, pagal perkamosios galios standartą. [žiūrèta 2020-02-10]. Internetinè prieiga: https://ec.europa.eu/eurostat/data/database.

7. Eurostat, 2020. Gini koeficientas. [žiūrèta 2019-12-01]. Prieiga per internetą: https://ec.europa.eu/eurostat/databrowser/view/tessi190/default/table?lang=en

8. Eurostat. 2020. Iš atsinaujinančių šaltinių gaunamos energijos dalis. [žiūrèta 2020-02-12]. Internetine prieiga: https://ec.europa.eu/eurostat/data/database.

9. Eurostat. 2020. Nedarbo lygis (tūkst. Gyventojų ir procentai). [žiūrèta 2020-02-14]. Internetinè prieiga: https://ec.europa.eu/eurostat/data/database.

10. Eurostat. 2020. Skurdo rizikos lygis. [žiūrèta 2020-02-09]. Internetinè prieiga: https://ec.europa.eu/eurostat/data/database.

11. Eurostat. 2020. Šiltnamio dujų emisijos. [žiūrèta 2020-02-25]. Internetinè prieiga: https://ec.europa.eu/eurostat/databrowser/view/sdg_13_10/default/table?lang=en

12. Eurostat, 2020. Oro tarša procentais. [žiūrèta 2020-02-10]. Internetinè prieiga: https://appsso.eurostat.ec.europa.eu/nui/submitViewTableAction.do

13. Griggs ir kiti. Sustainable development goals for people and planet. Nature 495, 305-307 (2013). [žiūrèta 2020-02-09]. Internetinè prieiga: https://sustainabledevelopment.un.org/content/documents/1696griggs2.pdf

14. Gruževskis B., Brazienè R., Krutulienė S. Lietuvos socialinė raida. Darbo rinkos pokyčiai: problemos ir galimybès. Lietuvos socialinių tyrimų centras, Vilnius, 2017. [žiūrèta 2020-0209]. Internetinè prieiga: https://1stc.lt/download/Lietuvos_socialine_raida_2017.pdf

15. Morel, N., \& Palier, B. (Eds.). (2011). Towards a social investment welfare state?: ideas, policies and challenges. Policy Press.

16. JT Darnaus vystymosi darbotvarkès iki $2030 \mathrm{~m}$. igyvendinimo Lietuvoje ataskaita. Respublikos Vyriausybės kanceliarija ir Aplinkos ministerija, 2018. [žiūrèta 2020-02-09]. Internetinè prieiga: http://am.lrv.lt/uploads/am/documents/files/ES_ir_tarptautinis_ bendradarbiavimas/Darnaus\%20vystymosi\%20tikslai/DV\%20ataskaita/ataskaita\%20LT.pdf 
17. Kardelis K. (2002). Mokslinių tyrimų metodologija ir metodai. 2-asis pataisytas ir papildytas leidimas. Kaunas.

18. Komunikatas (KOM(2010) 2020 galutinis) „2020 m. Europa. Pažangaus, tvaraus ir integracinio augimo strategija“. [žiūrèta 2020-02-25]. Internetinè prieiga: https:/eurlex.europa.eu/legal-content/LT/TXT/?uri=LEGISSUM\%3Aem0028.

19. Kveselis V., Dzenajavičienė E. F., Lisauskas A. Atsinaujinančių energijos išteklių technologijų ekologiškumas - ką apie tai turètų žinoti visuomené. Lietuvos energetikos institutas, Kaunas, 2013. [žiūrèta 2020-02-25]. Internetinè prieiga: https://alytauskolegija.lt/Dokumentai/2013/20_Kveselis.pdf

20. Lietuvos Respublikos aplinkos ministerija. JT Darbotvarkè 2030, darnaus vystymosi tikslai ir kiti tarptautiniai susitarimai, 2019. [2020-02-16]. Internetinè prieiga: http://am.lrv.lt/lt/

21. Marten, G., G. Human ecology. Basic concepts for sustainable development. Routledge. London, New York, 2010.

22. McLeod S. A. Simply psychology. Maslow's Hierarchy of Needs, 2018. [2020-02-10]. Internetinè prieiga: https://www.simplypsychology.org/maslow.html

23. Morel N., Palier B., Palme J. (2012). Towards a Social Investment Welfare State? Ideas, policines and challenges. Policy press. Great Britain. [žiūrèta 2020-02-25]. Internetinè prieiga: https://www.researchgate.net/publication/258646263_Towards_a_Social_ Investment_Welfare_State_Ideas_Policies_and_Challenges

24. Murphy K. 2012. The social pillar of sustainable development: a literature review and framework for policy analysis. Sustainability: Science, Practice and Policy, 8:1, pp. 15-29. DOI: $10.1080 / 15487733.2012 .11908081$

25. Nakicenovic N. The World in 2050 (TWI2050): Pathways toward sustainable future, Annual Meeting. International Institute for Applied Systems Analysis. Transitions To New Technologies, 2017. [žiūrèta 2020-02-25]. Internetinè prieiga: https://iiasa.ac.at/web/ home/research/researchPrograms/TransitionstoNewTechnologies/170403-TWI2050.html

26. Palidauskaitė J. Korupcijos ir atsakomybės problema viešojo administravimo sistemoje. Viešoji politika ir administravimas. Kauno technologijos universitetas, 2005. [žiūrèta 202002-25]. Internetinè prieiga: https://www.mruni.eu/upload/iblock/9f6/3_j.palidauskaite.pdf

27. Sachs, J., D. The age of sustainable development. Columbia university press, New York, 2015.

28. Sachs, J., Schmidt-Traub, G., Kroll, C., Lafortune, G., Fuller, G. 2019. Sustainable Development Report 2019. New York: Bertelsmann Stiftung and Sustainable Development Solutions Network (SDSN). [žiūrèta 2020-02-25]. Internetinè prieiga: https://sdgindex.org/reports/sustainable-development-report-2019/

29. Skučienè D. (2008). Pajamų nelygybè Lietuvoje. Filosofija, sociologija, 2008. Lietuvos mokslų akademijos leidykla. T. 19. Nr. 4, p. 22-33. [žiūrèta 2020-02-25]. Internetinè prieiga: https://etalpykla.lituanistikadb.lt/object/LT-LDB0001:J.04 2008 1367163079280/J.04 2008 1367163079280.pdf

30. Skučienė D., Gabnytė V. (2018). Skurdas kaimo vietovèse Lietuvoje. Vilniaus universitetas, LSTC Socialinès gerovès institutas. Lietuvos socialinè raida. 2018 Nr.7. 48-62. [žiūrèta 202002-25]. Internetinė prieiga: https://lstc.lt/download/Lietuvos_socialine_raida_2018_visas.pdf

31. Smalskys V., Šilinskytė A.(2016). Visuomenès itraukimas i Lietuvos vietos savivaldos valdymą duomenų atvirumo kontekste. Viešoji politika ir administravimas 4:641-656. [žiūrèta 2020-02-25]. Internetinè prieiga: https://www.ceeol.com/search/article-detail?id=479648

32. Trading economics. Coruuption rank. 2020. [2020-02-16]. Internetinè prieiga: https://tradingeconomics.com/corruption-rank.

33. Urbanavičiūtė S., Ruževičius J. Anglies dvideginio pėdsakas darnaus vystymosi kontekste. Vilniaus universitetas, 2016. [2020-02-20]. Internetinè prieiga: http://acta.avada.lt/images/dokumentai/acta_avada_2016.pdf 


\section{Kantautė Augaitytė \\ Analysis of the implementation of sustainable development goals in the Baltic States}

Anotacija

This article analyzes the progress of the Baltic States in achieving the goals of sustainable development. Scientific literature with a focus on the concept of sustainable development is analyzed. A holistic approach to the perception of sustainable development and a comprehensive approach to the pursuit of sustainable development are presented. The article uses the 2015 The United Nations Agenda for Sustainable Development and its objectives nerandu Google tokio daikto. According to the International Institute of Applied Systems Analysis (IIASA), all objectives are divided into six key areas: global values, resource efficiency, environmental conditions, meeting human needs, socioeconomic growth, governance and partnership. According to these areas, the main indicators of the Baltic States are analyzed (Gini coefficient, the share of energy from renewable sources, greenhouse gas emissions, at-risk-of-poverty rate, unemployment rate, government expenditure on health care and education, percentage of GDP). According to the indicators analyzed, the weakest areas in each of the Baltic States are singled out and the trends are reflected in all the Baltic States, i.e. Lithuania, Latvia and Estonia.

Kantautè Augaitytė - socialinių mokslų magistrantè, Kauno technikos universitetas, Lietuva email: kantaute.aug@gmail.com

Kantaute Augaityte - master student in social sciencies, Kaunas University of technilogy, Lithuania email: kantaute.aug@gmail.com 